\begin{tabular}{|c|c|c|c|}
\hline $\begin{array}{l}\text { 2. To: (Receiving Organization) } \\
327 \text { Deactivation Project }\end{array}$ & \multicolumn{2}{|c|}{$\begin{array}{l}\text { 3. From: (Originating Organization) } \\
327 \text { Deactivation Project }\end{array}$} & $\begin{array}{r}\text { 4. Related EDT No.: } \\
\text { NA }\end{array}$ \\
\hline $\begin{array}{l}\text { 5. Proj./Prog./Dept./Div.: } \\
327 \text { Deactivation Project }\end{array}$ & \multicolumn{2}{|c|}{$\begin{array}{l}\text { 6. Design Auth./Design Agent/Cog. Eng.: } \\
\text { TL Erickson / SK Fong }\end{array}$} & $\begin{array}{c}\text { 7. Purchase Order No.: } \\
\text { NA }\end{array}$ \\
\hline \multirow{2}{*}{\multicolumn{3}{|c|}{$\begin{array}{l}\text { 8. Originator Remarks: } \\
\text { This supporting document provides the documentation on the critical characteristics } \\
\text { of commercial grade items as required by HNF-PRO-268, Control of Purchased Items and } \\
\text { Services. }\end{array}$}} & $\begin{array}{c}\text { 9. Equip./Component No.: } \\
\text { NA }\end{array}$ \\
\hline & & & $\begin{array}{r}\text { 10. System/BIdg./Facil ity: } \\
327 / \text { PITF }\end{array}$ \\
\hline \multirow{4}{*}{ 11. Receiver Remarks: } & Design Basel ine Document? $\quad[\mathrm{x}]$ & \multirow{4}{*}{ Yes [] No } & 12. Major Assm. Dwg. No.: \\
\hline & \multirow{3}{*}{ 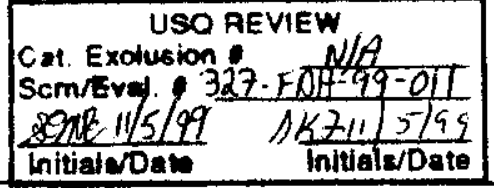 } & & NA \\
\hline & & & $\begin{array}{l}\text { 13. Permit/Permit Application No.: } \\
\text { NA }\end{array}$ \\
\hline & & & $\begin{array}{l}\text { 14. Required Response Date: } \\
11-10-99\end{array}$ \\
\hline
\end{tabular}

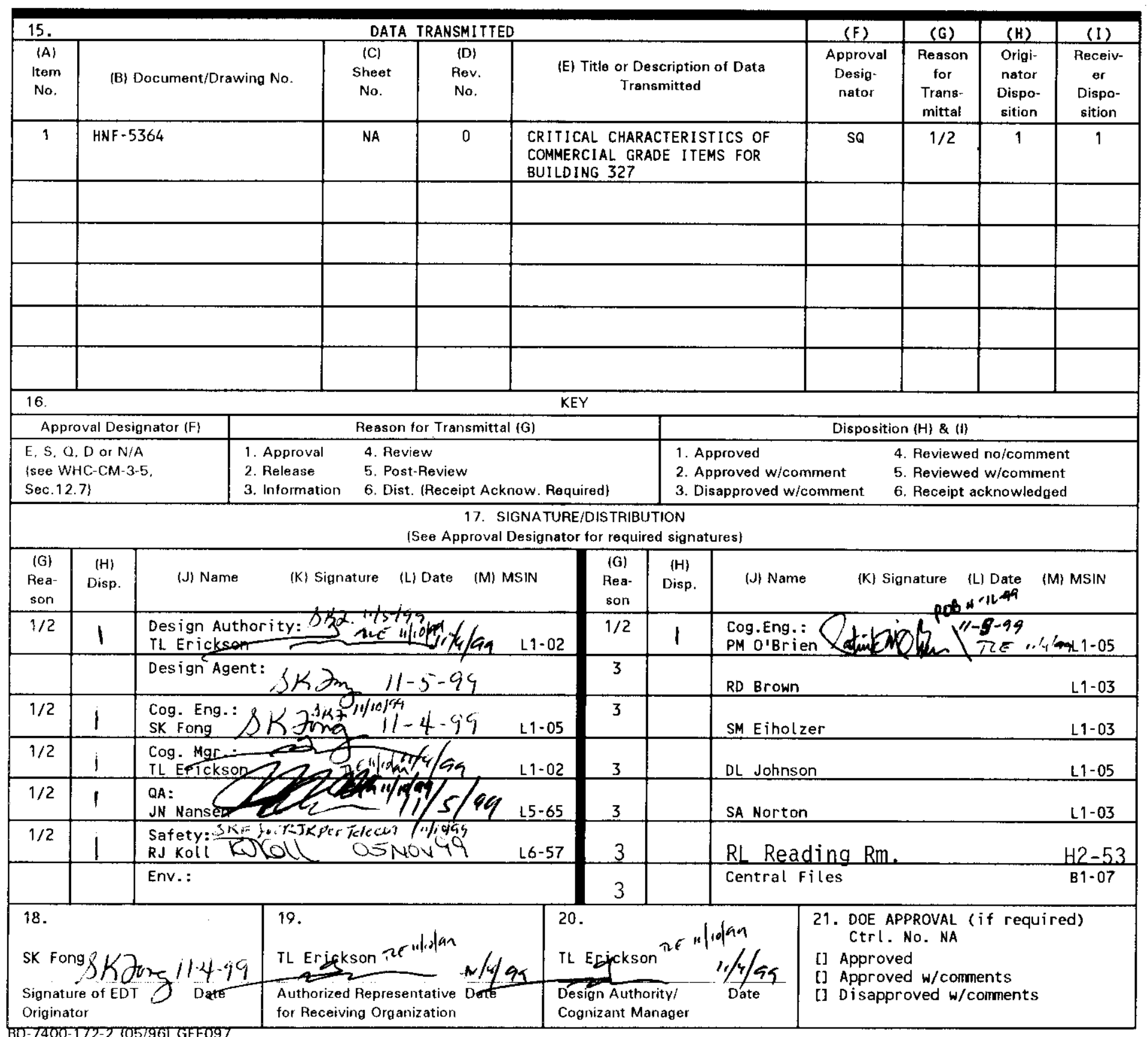




\section{CRITICAL CHARACTERISTICS OF COMMERCIAL GRADE ITEMS FOR BUILDING 327}

S. K. Fong

BWHC, Richland, WA 99352

U.S. Department of Energy Contract DE-AC06-96RL13200

EDT/ECN: EDT 617711 UC: 900

Org Code: 19200

B\&R Code: NA

Charge Code: 101159 AJ60

Total Pages: 10 ga 11

Key Words: CGI, commercial grade item, building 327, HNF-5364

Abstract: This document will be used to document the critical characteristics of safety related items procured as commercial grade items to satisfy requirements in HNF-PRO-268, Control of Purchased Items and Services. The critical characteristics and the dedication methods will be listed in the form provided and attached to the appendix of the supporting document as required by this procedure.

TRADEMARK DISCLAIMER. Reference herein to any specific commercial product, process, or service by trade name, trademark, manufacturer, or otherwise, does not necessarily constitute or imply its endorsement, recommendation, or favoring by the United States Government or any agency thereof or its contractors or subcontractors.

Printed in the United States of America. To obtain copies of this document, contact: Document Control Services, P.0. Box 950, Mailstop H6-08, Richland WA 99352, Phone (509) 372-2420;

Fax (509) 376-4989.

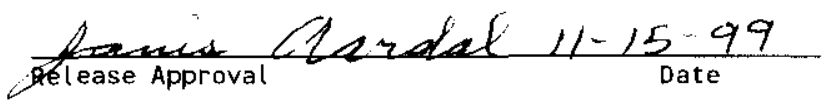

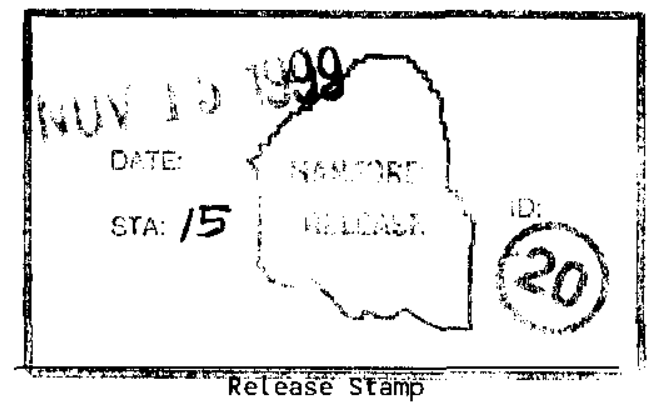


HNF-5364, REV 0

\section{CRITICAL CHARACTERISTICS OF COMMERCIAL GRADE ITEMS}

FOR BUILDING 327 


\section{CRITICAL CHARACTERISTICS OF COMMERCIAL GRADE ITEMS}

FOR BUILDING 327

\section{TABLE OF CONTENTS}

\subsection{PURPOSE}

2.0 SCOPE

3.0 DEFINITIONS

4.0 CRITICAL CHARACTERISTICS

4.1 Material Characteristics

4.2 Configuration Characteristics

4.3 Functional Characteristics

4.4 Qualification Characteristics

4.5 Identification Characteristics

5.0 DEDICATION

5.1 Conditioning

5.2 Inspections and Tests

6.0 MAINTENANCE OF THIS DOCUMENT

CRITICAL CHARACTERISTICS FORM

COMMERCIAL GRADE ITEM INDEX

ATTACHMENTS 


\section{CRITICAL CHARACTERISTICS OF COMMERCIAL GRADE ITEMS FOR BUILDING 327}

\subsection{PURPOSE}

The purpose of this document is to specify the critical characteristics of Commercial Grade Items (CGI). CGI having these critical characteristics are considered acceptable for their intended use.

\section{$2.0 \quad$ SCOPE}

This document applies to CGI used in Safety Class and Safety Significant applications or in General Service applications involving high project risk at the 327 facility.

\subsection{DEFINITIONS}

Commercial Grade Item. An item that: (a) is not subject to design or specification requirements that are unique to nuclear facilities; (b) is used in applications other than nuclear facilities; and (c) is to be purchased from the manufacturer/supplier on the basis of specifications set forth in his published product description.

Conditioning. Modifications, treatments, and/or processes performed on a CGI to ensure it will perform its intended function.

Critical Characteristic. A property or attribute of an item's material composition, configuration, function, qualification, and/or identification that is: (a) essential for it to perform its intended function and (b) that can be verified through inspection and/or test.

Dedication. The process of conditioning, inspecting, and/or testing a CGI to ensure and document that it has the specified critical characteristics and is, therefore, acceptable for its intended use.

\subsection{CRITICAL CHARACTERISTCS}

There are five types of critical characteristics: material characteristics, configuration characteristics, functional characteristics, qualification characteristics, and identification characteristics.

\subsection{Material Characteristics}

Material characteristics relate to the physical attributes of the materials used in the manufacture of the item. These can include, but are not limited to chemical composition, ductility, hardness, concentration, tensile strength, density, resistance, conductivity, viscosity, capacitance, color, and permeability.

\subsection{Configuration Characteristics}

Configuration characteristics relate to the physical arrangement of the materials used in the manufacture of the item. These can include, but are not limited to dimensions, quantities, weights, shapes, surface finish, scales, and ranges. 


\section{CRITICAL CHARACTERISTICS OF COMMERCIAL GRADE ITEMS FOR BUILDING 327}

\subsection{Functional Characteristics}

Functional characteristics relate to the operation of the item. These can include, but are not limited to speed, time response, accuracy, repeatability, reliability, outputs (e.g., voltage, current, pressure, volume, and temperature), power, strength, capacity, leakage, and noise.

\subsection{Qualification Characteristics}

Qualification characteristics relate to specific qualifications and endorsements the item must meet to ensure it will perform its intended function. These can include, but are not limited to environmental and seismic qualifications, and endorsements from independent agencies and authorities (e.g., NFPA and UL).

\subsection{Identification Characteristics}

Identification characteristics relate to the markings and labels on the item or its container. These markings and labels can include, but are not limited to the manufacturer's item identification (e.g., part number, model number, and manufacturer's name) and other critical characteristics (e.g., size, type, range, weight, and pressure).

\subsection{DEDICATION}

Dedication methods include, but are not limited to conditioning, source inspection/testing, receiving inspection/testing, and pre/post installation inspection/testing.

\subsection{Conditioning}

Conditioning can include, but is not limited to modifications (e.g., adding reinforcement, removing interferences, and changing mounts and connectors), special treatments (e.g., heat treatments, applying special coatings, and surface finishing), and processes (e.g., burn-in and shaker tests), which are done to ensure the item will perform its intended function. Conditioning requirements shall be tied to specific critical characteristics, and shall be identified in applicable procurement documents (if a vendor performs the conditioning) and/or in work documents (if the conditioning is performed in-house) by inclusion or reference to the applicable attachment of this document.

\subsection{Inspections and Tests}

Critical characteristics that are to be verified during source/receiving inspections shall be identified in applicable procurement documents and Quality Assurance Inspection Plans. Critical characteristics that are to be verified during or after installation shall be identified in applicable work documents (e.g., JCS work packages and technical work plans). Critical characteristics may be identified in procurement documents, Quality Assurance Inspection Plans, and work documents by inclusion or reference to the applicable attachment of this document. 


\section{CRITICAL CHARACTERISTICS OF COMMERCIAL GRADE ITEMS FOR BUILDING 327}

\subsection{MAINTENANCE OF THIS DOCUMENT}

Critical characteristics and methods for their verification, and conditioning requirements, shall be specified by the Design Authority on the Critical Characteristics form. Each form shall be numbered to correspond with the discipline to which the item applies (i.e., C. 1 would be the first $\mathrm{CGl}$ in the Civil/Structural section; E.1 for the electrical, I.1 for the instrumentation; and M.1 for the mechanical). The completed form shall be incorporated into this document as an attachment using an Engineering Change Notice (ECN). The ECN shall also update the Commercial Grade Item Index. 


\section{CRITICAL CHARACTERISTICS OF COMMERCIAL GRADE ITEMS \\ FOR BUILDING 327}

\section{Critical Characteristics Form}

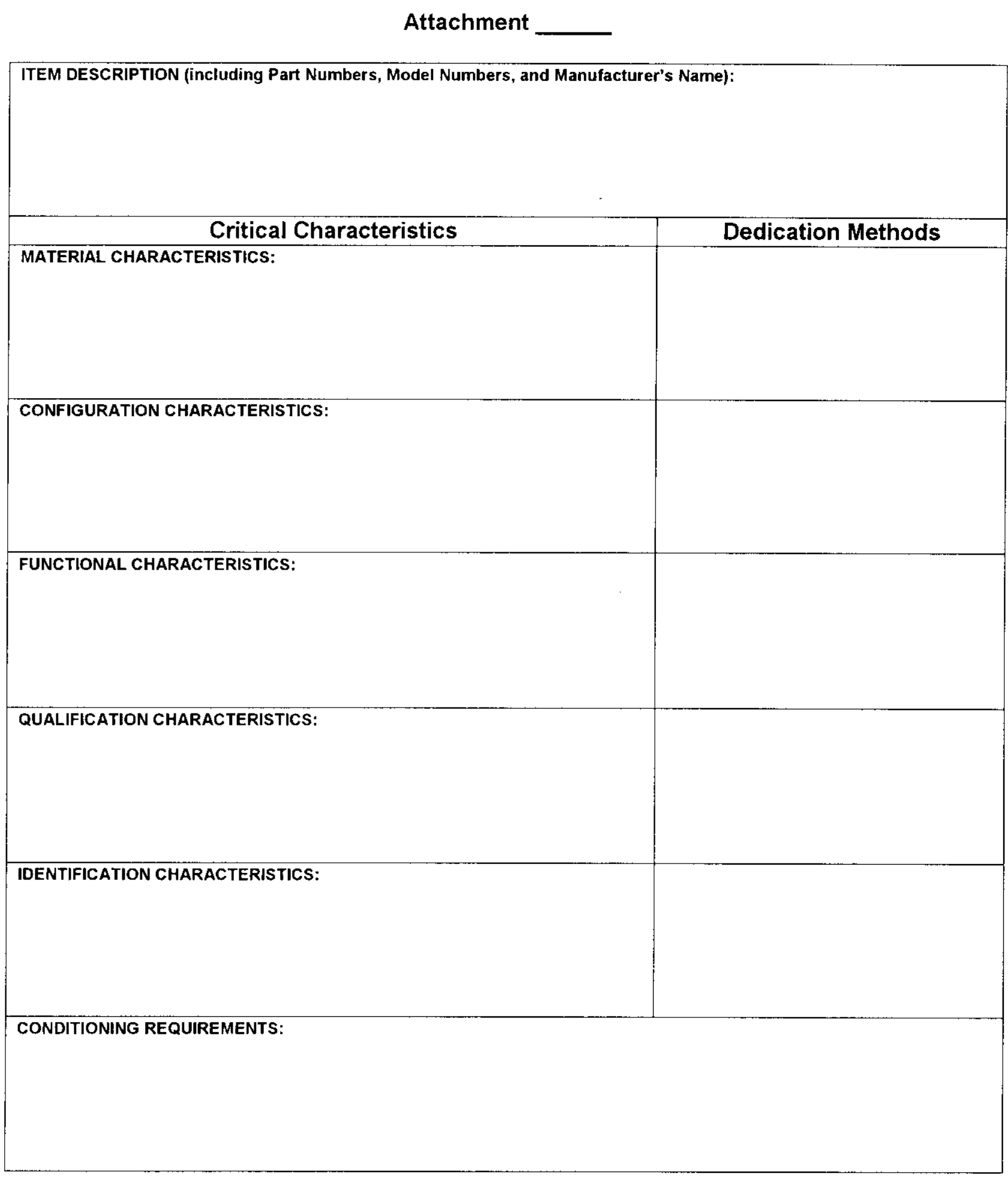




\section{CRITICAL CHARACTERISTICS OF COMMERCIAL GRADE ITEMS}

FOR BUILDING 327

\section{COMMERCIAL GRADE TEM NDEXX}

Commercial Grade Item Description

Attachment

Number

\section{Civilstructural lems}

\section{Electrical ltems}

Battery, sealed valve regulated lead acid, Best Power BAT0370

E.1

Light, pilot light, LED, 120 VAC-DC, $30 \mathrm{~mm}$, heavy duty, oil/rain

tight, Square D, Class 9001, \#KP38LRR31 or \#KP38LGG31

3. Instrument ltems

\section{Mechanical ltems}


CRITICAL CHARACTERISTICS OF COMMERCIAL GRADE ITEMS

FOR BUILDING 327

\section{ATTACHMENTS}

(IN ALPHANUMERIC SEQUENCE) 


\section{CRITICAL CHARACTERISTICS OF COMMERCIAL GRADE ITEMS FOR BUILDING 327}

\section{Critical Characteristics Form}

\begin{tabular}{|c|c|}
\hline \multicolumn{2}{|l|}{ Attachment E.1 } \\
\hline \multicolumn{2}{|c|}{$\begin{array}{l}\text { ITEM DESCRIPTION (including Part Numbers, Model Numbers, and Manufacturer's Name): } \\
\text { Battery, sealed valve regulated lead acid, } 12 \text { VDC, replacements for Best Fortress UPS Mode } \\
\text { LI-660VAB } \\
\text { P/N: BAT0370 } \\
\text { UPS Manufacturer: Best Power Technologies, Inc. }\end{array}$} \\
\hline Critical Characteristics & Dedication Methods \\
\hline $\begin{array}{l}\text { MATERIAL CHARACTERISTICS: } \\
\text { Sealed valve regulated lead acid battery. }\end{array}$ & Pre-installation inspection \\
\hline $\begin{array}{l}\text { CONFIGURATION CHARACTERISTICS: } \\
\text { None. }\end{array}$ & \\
\hline $\begin{array}{l}\text { FUNCTIONAL CHARACTERISTICS: } \\
\text { Voltage: } 12 \text { VDC } \\
\text { Rating: } 12 \mathrm{~V}, 6.5 \text { amp-hour @ } 20 \mathrm{hr} \text { minimum or equivalent }\end{array}$ & $\begin{array}{l}\text { Pre-installation inspection } \\
\text { Pre-installation testing }\end{array}$ \\
\hline $\begin{array}{l}\text { QUALIFICATION CHARACTERISTICS: } \\
\text { None. }\end{array}$ & \\
\hline $\begin{array}{l}\text { IDENTIFICATION CHARACTERISTICS: } \\
\text { Best Power Technologies, Inc. P/N: BAT0370 } \\
\text { (Note: The battery supplied may be manufactured by a } \\
\text { vendor other than Best Power Technologies, Inc.) }\end{array}$ & Receiving inspection \\
\hline $\begin{array}{l}\text { CONDITIONING REQUIREMENTS: } \\
\text { None. }\end{array}$ & \\
\hline
\end{tabular}




\section{CRITICAL CHARACTERISTICS OF COMMERCIAL GRADE ITEMS FOR BUILDING 327}

\section{Critical Characteristics Form}

\section{Attachment E.2}

\begin{tabular}{|c|c|}
\hline \multicolumn{2}{|l|}{$\begin{array}{l}\text { ITEM DESCRIPTION (including Part Numbers, Model Numbers, and M } \\
\text { Light, pilot light, LED, } 120 \text { VAC-DC, heavy duty, oil tig } \\
\text { P/N (red lens): Class } 9001, \text { KP38LRR31, or } \\
\text { P/N (green lens): Class } 9001, \text { KP38LGG31 } \\
\text { Manufacturer: Square D }\end{array}$} \\
\hline Critical Characteristics & Dedication Methods \\
\hline $\begin{array}{l}\text { MATERIAL CHARACTERISTICS: } \\
\text { Lamp type: LED }\end{array}$ & Pre-installation inspection \\
\hline $\begin{array}{l}\text { CONFIGURATION CHARACTERISTICS: } \\
\text { Size: } 30.5 \mathrm{~mm} \text { configuration } \\
\text { Other: Oil tight, rain tight }\end{array}$ & Pre-installation inspection \\
\hline $\begin{array}{l}\text { FUNCTIONAL CHARACTERISTICS: } \\
\text { Voltage rating: } 120 \text { VAC-DC nominal }\end{array}$ & $\begin{array}{l}\text { Pre-installation inspection } \\
\text { Post-installation test }\end{array}$ \\
\hline $\begin{array}{l}\text { QUALIFICATION CHARACTERISTICS: } \\
\text { UL listed }\end{array}$ & Pre-installation inspection \\
\hline $\begin{array}{l}\text { IDENTIFICATION CHARACTERISTICS: } \\
\text { Square D, P/N (red lens): Class 9001, KP38LRR31 or } \\
\text { P/N (greed lens): Class 9001, KP38LGG31 }\end{array}$ & Receiving inspection \\
\hline $\begin{array}{l}\text { CONDITIONING REQUIREMENTS: } \\
\text { None. }\end{array}$ & \\
\hline
\end{tabular}

